\title{
PENGARUH PARTISIPASI PENYUSUNAN ANGGARAN TERHADAP KINERJA MANAJERIAL DENGAN GAYA KEPEMIMPINAN, MOTIVASI DAN JOB RELEVANT INFORMATION SEBAGAI VARIABEL INTERVENING
}

\author{
Caesar Arif Budiman ${ }^{*}$, Ria Nelly Sari² dan Vince Ratnawati ${ }^{2}$ \\ ${ }^{1}$ Program Studi Magister Akuntansi Pasca Sarjana Universitas Riau \\ ${ }^{2}$ Fakultas Ekonomi Universitas Riau \\ Email :caesararif@yahoo.co.id
}

\begin{abstract}
: this study aimed to determine (1) the effect of budgetary participation on managerial performance in the preparation of the budget, (2) the effect of leadership style on the relationship between budgetary participation and managerial performance, (3) the effect of motivation on the relationship between budgetary participation and managerial performance, and (4) the effect of job relevant information on the relationshipbetween budgetary participation and managerial performance. The subjects of this study are all managers in bank riau kepri. The data was collected by distributing questionnaires to 138 respondents, but only 85 respondents who fill out the questionnaires. The analysis tool is using Partial Least Square (PLS) program version 2.0. The result show that budgetary participation has positive and significant effect on managerial performance. Furthermore, job relevant information has positive and significant effect with budgetary participation and the managerial performance. The data of this study failed to support the mediating rate of leadership style and motivation on the relationship between budgetary participation and the managerial performance.
\end{abstract}

Keywords: budgetary participation, leadership style, motivationt job relevant information, and managerial performance.

\section{PENDAHULUAN}

Dalam era globalisasi saat ini, perkembangan persaingan usaha meningkat secara pesat. Untuk dapat bersaing secara sehat setiap perusahaan harus dapat menunjukkan kinerja yang baik. Kinerja menjadi gambaran mengenai tingkat pencapaian pelaksanaan suatu kegiatan dalam mewujudkan sasaran, tujuan, visi dan misi organisasi yang tertuang dalam strategi perencanaan suatu organisasi. Selain itu kinerja suatu organisasi dapat dilihat dari tingkatan sejauh mana organisasi dapat mencapai tujuan yang sudah ditetapkan sebelumnya.

Kinerja organisasi yang dihasilkan tersebut erat kaitannya dengan kinerja manajerial. Hal ini dikarenakan semakin baiknya kinerja seorang manajer akan berpengaruh dengan semakin baiknya kinerja organisasi tersebut. Kinerja manajerial ini membantu perusahaan untuk mencapai sebuah kinerja organisasi yang baik dengan segala arah dan tindakan yang dilakukan oleh manajer.

Untuk mencapai kinerja manajerial yang baik dibutuhkan sebuah 
perencanaan yang baik. Perencanaan merupakan tindakan yang dibuat berdasarkan fakta dan asumsi mengenai gambaran kegiatan yang dilakukan pada waktu yang akan datang dalam mencapai tujuan yang diinginkan (Nafarin, 2004). Dalam suatu perencanaan membuat anggaran merupakan komponen yang penting.

Anggaran adalah suatu rencana yang disusun secara sistematis yang meliputi seluruh kegiatan perusahaan, yang dinyatakan dalam unit (kesatuan) moneter dan berlaku untuk jangka waktu (periode) tertentu yang akan datang (Munandar, 2001:1). Sebagai alat perencanaan, anggaran merupakan rencana kegiatan yang terdiri dari sejumlah target yang akan dicapai oleh para manajer departemen suatu perusahaan dalam melaksanakan serangkaian kegiatan tertentu pada masa yang akan datang.

Proses penyusunan anggaran, dapat dilakukan dengan beberapa pendekatan yaitu top-down, bottom up dan partisipasi (Ramadhani dan Nasution, 2009). Proses penyusunan anggaran dengan metode top - down merupakan penganggaran yang keseluruhannya disusun dan disahkan oleh pihak manajemen level atas dan pihak manajemen level bawah hanya melaksanakan anggaran yang telah disahkan. Sedangkan proses penyusunan anggaran bottom up (partisipatip) merupakan penyusunan anggaran dengan memberikan kewenangan kepada pihak manajemen level bawah untuk kemudian diajukan kepihak manajer atas.

Penganggaran partisipatif (participative budgeting) merupakan pendekatan penganggaran yang berfokus pada upaya untuk meningkatkan motivasi karyawan untuk mencapai tujuan organisasi. Penyusunan anggaran partisipatif akan memberikan motivasi kerja kepada individu yang terlibat dalamnya. Motivasi merupakan keadaan dalam pribadi seseorang yang mendorong keinginan individu melakukan kegiatan-kegiatan tertentu untuk mencapai tujuan (Narmodo dan Wajdi, 2007). Narmodo dan Wajdi (2007) menyebutkan bahwa motivasi pada dasarnya adalah proses yang menentukan seberapa banyak usaha yang akan dicurahkan untuk melaksanakan pekerjaan. Motivasi atau dorongan untuk bekerja ini sangat menetukan bagi tercapainya suatu tujuan.

Partisipasi didalam penyusunan anggaran diyakini mempunyai pengaruh positif terhadap motivasi karyawan dalam meningkatkan kuantitas dan kualitas produksi dan kerjasama diantara para manajer. Maka, manusia harus dapat menumbuhkan motivasi kerja setingi-tingginya bagi para karyawan dalam perusahaan. Jadi dengan adanya partisipasi penyusunan anggaran, kinerja pegawai akan meningkat karena komunikasi antara bawahan dengan atasan dalam membuat keputusan bersama menimbulkan motivasi dalam bekerja.

Kinerja pegawai tidak lepas dari peran pemimpinnya. Menurut Bass (1990), peran pemimpin dalam memberikan kontribusi pada karyawan untuk 
pencapaian kinerja yang optimal dilakukan melalui lima cara,yaitu: (1) pemimpin mengklarifikasi harapan perusahaan terhadap karyawannya mengenai tujuan dan sasaran kinerja mereka,(2) pemimpin menjelaskan bagaimana memenuhi harapan tersebut, (3) pemimpin mengemukakan kriteria dalam melakukan evaluasi dari kinerja secara efektif, (4) pemimpin memberikan umpan balik ketika karyawan telah mencapai sasaran, dan (5) pemimpin mengalokasikan imbalan berdasarkan hasil yang telah mereka capai.

Kepemimpinan yang efektif dapat memberikan pengarahan terhadap usaha dalam mencapai tujuan organisasi (Decoster dan Fertakis, 1968). Untuk menciptakan kepemimpinan yang efektif tersebut, informasi mengenai perusahaan juga dibutuhkan oleh seorang manajer dalam membantu memberikan pengetahuan yang lebih baik bagi manajer mengenai alternatif keputusan dan tindakan yang dibutuhkan untuk mencapai tujuan. Kren (1992) mengidentifikasi dua jenis informasi utama dalam organisasi yaitu decision influencing dan job relevant information (JRI). Decision influencing merupakan informasi yang dikumpulkan manajer tentang perilaku seseorang untuk tujuan evaluasi kinerja, sedangkan job relevant information merupakan informasi yang membantu manajer untuk meningkatkan kinerjanya dengan informasi lebih baik. JRI menjadi jenis informasi yang sangat penting bagi manajer untuk meningkatkan kinerjanya.

JRI meningkatkan kinerja melalui pemberian perkiraan yang lebih akurat mengenai lingkungan sehingga dapat dipilih rangkaian tindakan efektif yang terbaik. Merchant (1981), Chow et al. (1988) serta Nouri dan Parker (1998) dalam Omposunggu dan Bawono (2006) menyatakan bahwa apabila bawahan atau pelaksana anggaran ikut berpartisipasi dalam penyusunan anggaran maka mereka akan mengungkapkan informasi privat yang mereka miliki. Informasi yang belum diketahui sebelumnya oleh atasan tersebut dapat meningkatkan akurasi pemahaman terhadap bawahan atau pelaksana anggaran sehingga semakin mengurangi informasi asimetris dalam hubungan antara pemegang kuasa anggaran dengan pelaksana anggaran.

Sembiring (2008) menemukan bahwa adanya pengaruh yang signifikan antara partisipasi penyusunan anggaran dan kejelasan sasaran anggaran terhadap kinerja manajerial. Pada penelitian ini motivasi berperan sebagai variabel intervening dalam mempengaruhi hubungan antara partisipasi anggaran dengan kinerja manajerial, hal ini dibuktikan dengan tingkat nilai signifikan partisipasi anggaran $\mathrm{p}=0.001$ dan signifikan motivasi kerja $\mathrm{p}=0.00$, lebih kecil dari 0.05, yang menunjukkan adanya hubungan signifikan antara partisipasi anggaran terhadap kinerja manajerial melalui motivasi kerja. Akan tetapi motivasi tidak dapat sebagai variabel intervening dalam mempengaruhi hubungan kejelasan sasaran anggaran terhadap kinerja manajerial, hal ini dikarenakan hasil perhitungan pengaruh langsung kejelasan sasaran anggaran terhadap kinerja manajerial lebih besar dari pengaruh tidak langsung antara 
kejelasan sasaran anggaran terhadap kinerja manajerialyang di mediasi oleh motivasi. Dengan adanya motivasi sebagai variabel intervening tidak meningkatkan signifikansi pengaruh kejelasan sasaran anggaran terhadap kinerja manajerial.

Berdasarkan penjelasan diatas dapat disimpulkan bahwa kinerja manajerial dapat ditingkatkan melalui partisipasi manajer dalam penyusunan anggaran. Namun pengaruh partisipasi anggaran terhadap kinerja manajerial belumlah bersifat langsung tetapi dapat dimediasi atau di intervening oleh beberapa variabel seperti motivasi, ketersediaan informasi yang relevan (JRI), dan gaya kepemimpinan.

Penelitian ini mengambil objek penelitian dalam perbankan yaitu Bank Riau Kepri, hal ini dilakukan untuk lebih mengetahui pengaruh partisipasi penyusunan anggaran terhadap kinerja manajerial dengan variabel intervening gaya kepemimpinan, motivasi dan job relevant information. Dengan dilakukannya penelitian ini diharapkan Bank Riau Kepri dapat lebih meningkatkan kinerja yang telah ada, terutama dalam menghadapi persaingan usaha perbankan yang ada saat ini maupun masa yang akan datang.

Bank Riau Kepri yang merupakan badan usaha milik daerah (BUMD) yang sahamnya dimiliki oleh pemerintah daerah provinsi Riau dan Kepulauan Riau. Bank ini berdiri pada tanggal 1 april 1966 sebagai bank pembangunan daerah (BPD). Pada tanggal 22 Juli 2003 bank ini berubah status badan hukum bank pembangunan daerah Riau menjadi berbadan hukum PT. Saat ini bank riau kepri memiliki 19 kantor cabang, 38 kantor cabang pembantu, dan 24 kantor kedai.

\section{KERANGKA TEORITIS}

\section{Partisipasi Anggaran dan Kinerja Manajerial}

Partisipasi penyusunan anggaran merupakan aktivitas menyusun anggaran yang melibatkan setiap tingkat manajer. Anggaran yang disusun akan berpengaruh pada pembuatan keputusan dimasa yang akan datang. Partisipasi penyusunan anggaran akan mempengaruhi kinerja manajerial, karena dengan adanya partisipasi penyusunan anggaran maka manajer yang merasa terlibat akan bertanggung jawab pada pelaksanaan anggaran sehingga bawahan diharapkan akan melaksanakan anggaran dengan lebih baik

Menurut Sinambela (2003), partisipasi dalam penyusunan anggaran dinilai sebagai pendekatan manajerial yang dapat meningkatkankinerja organisasi. Manajer yang terlibat dalam penyusunan anggaran akan lebih berusaha untuk memahami dan berusaha untuk mencapai tujuan anggaran. Sehingga Para manajer akan lebih bertanggung jawab dan bersungguh-sungguh dalam pelaksanaan anggaran dan menyebabkan kinerja manajerialnya akan 
meningkat.

Brownel dan McInnes (1986), melakukan penelitian terhadap manajer tingkat menengah pada perusahaan manufaktur, Brownel dan McInnes (1986) menemukan bukti bahwa partisipasi penyusunan anggaran mempengaruhi kinerja manajerial.Laberto (2001), juga membuktikan bahwa partisipasi anggaran berpengaruh positif dan signifikan terhadap kinerja manajerial. Dengan adanya partisipasi penyusunan anggaran maka kinerja manajerial diharapkan akan lebih meningkat.

Dari beberapa penjelasan diatas, maka dapat diajukan hipotesis sebagai berikut:H1: Partisipasi dalam penyusunan anggaran berpengaruh positif dan signifikan terhadap kinerja manajerial.

\section{Partisipasi Anggaran, Gaya Kepemimpinan, dan Kinerja Manajerial}

Partisipasi dalam penyusunan anggaran merupakan suatu proses kerja sama dalampembuatan keputusan yang melibatkan manajer atas dengan manajer bawahan untuk mencapai tujuan. Dalam keterlibatan penganggaran ini manajer atas selalu menerapkan kebijakan yang sesuai dengan gaya kepemimpinannya untuk mencapai kinerja manajerial yang baik.

Gaya kepemimpinan merupakan gaya norma perilaku yang dipergunakan oleh seseorangpadasaat mencobamempengaruhiperilakuoranglain ataubawahan. Pemimpin tidak dapat menggunakan gaya kepemimpinan yang sama dalam memimpin bawahannya, namun harus disesuaikan dengan karakter-karakter tingkat kemampuan dalam tugas setiap bawahannya (Mariam, 2009).

Menurut Baihaqi (2010) gaya kepemimpinan (leadership style) merupakan cara pimpinan untuk mempengaruhi orang lain atau bawahannya sedemikian rupa sehingga orang tersebut mau melakukan kehendak pimpinan untuk mencapai tujuan organisasi meskipun secara pribadi hal tersebut tidak disenangi. Gaya kepemimpinan ini erat hubungannya dengan kinerja, karena sering kali betah atau tidaknya seseorang terhadap pekerjaan itu ditentukan dari bagaimana cara memimpin perusahaan tersebut dan perlakuan terhadap bawahan.

Yuniarti (2008) dalam penelitiannya untuk melihat pengaruh gaya kepemimpinan terhadap hubungan antara partisipasi anggaran dengan kinerja manajerial menemukan hasil hubungan yang negatif antara partisipasi penyusunan anggaran dengan gaya kepemimpinan.Dalam hal ini partisipasi penyusunan anggaran yang tinggi tidak memiliki pengaruh terhadap gaya kepemimpinan manajemen dalam perusahaan. Sama halnyadengan Yuniarti (2008), Nor (2007) yang melakukan penelitian terhadap pengaruh partisipasi penyusunan anggaran dan kinerja manajerial dengan variabel moderating gaya kepemimpinan menemukan hasil yang signifikan antara partisipasi penyusunan anggaran dengan gaya kepemimpinan. Hal ini disebabkan oleh adanya faktor lain 
yang lebih dominan, faktor tersebut adalah budaya bangsa Indonesia yang masih diwarnai dengan budaya feodalis sehingga memungkinkan partisipasi yang diperankan sebenarnya merupakan pseudopatisipation, kelihatannya berpartisipasi, tetapi pada kenyataannya tidak berpartisipasi.

Penelitian dari Baihaqi (2010) membuktikan bahwa secara empiris gaya kepemimpinan mempunyai pengaruh positif dan signifikan terhadap kinerja. Pengaruh yang positif ini menunjukkan adanya pengaruh yang searah antara gaya kepemimpinan dengan kinerja karyawan, atau dengan kata lain dengan gaya kepemimpinan baik maka kinerja karyawan tinggi. Sedangkan pengaruh yang signifikan ini menunjukkan bahwa gaya kepemimpinan berpengaruh nyata terhadap kinerja.

Dari beberapa penjelasan diatas, maka dapat diambil hipotesis sebagai berikut: H2:Partisipasi dalam penyusunan anggaran berpengaruh positif dan signifikan terhadap kinerja manajerial dengan dimediasi oleh gaya kepemimpinan.

\section{Partisipasi Anggaran, Motivasi, dan Kinerja Manajerial}

Keterlibatan manajer dalam penganggaran memiliki pengaruh yang baik terhadapn motivasi manajer tersebut. Hal ini dikarenakan manajer yang ikut terlibat akan merasa dihargai karena ikut menentukan keputusan dimasa yang akan datang. Dengan dihargai dan dilibatkan dalam penyusunan anggaranmenimbulkan motivasi dari dalam diri manajer tersebut untuk menyelesaikan tugasnya dengan lebih baik. Jadi dengan adanya motivasi yang tinggi maka diharapkan akan meningkatkan kinerja manajerial manajer dalam menyelesaikan tugasnya.

Menurut Laberto (2001) dalam penelitiannya menemukan hubungan yang signifikan dan positif antara partisipasi anggaran terhadap motivasi kerja. Dengan tingkat motivasiyang tinggi cenderung mendorong manajer untuk lebih efektif di dalam memahami anggaran, dan manajer akan memiliki pemahaman yang baik dalam menghadapi kesulitan pada saat pelaksanaan anggaran. Penelitian inimembuktikan bahwa motivasi memiliki hubungan positif dan signifikan terhadap kinerja manajerial dalam artian semakin tinggi motivasi seorang manajer, maka semakin tinggi pula kinerja manajerial yang dihasilkan.

Senada dengan penelitian Laberto(2001), penelitian yangd ilakukan oleh Sembiring (2008) juga mendapati hubungan yang positif dan signifikan antara motivasi terhadap kinerja manajerial, dan motivasi adalah variabel intervening dari partisipasi anggaran terhadap kinerja manajerial.

Dari beberapa penjelasan diatas, maka dapat diambil hipotesis sebagai berikut: H3:Partisipasi dalam penyusunan anggaran berpengaruh positif dan signifikan terhadap kinerja manajerial dengan dimediasi oleh motivasi 


\section{Partisipasi Anggaran, Job Relevant Informasi, dan Kinerja Manajerial}

Partisipasi dalam anggaran memberikan kesempatan kepada manajer tingkat bawah untuk memberikan informasi untuk membantu dalam pembuatan keputusan. Ada dua jenis informasi utama dalam organisasi yaitu decision influencing dan job relevant information (JRI). Kedua informasiini berfungsidalam memfasilitasipembuatan keputusan yang berhubungan dengan tugas. Informasi yang releven akan membantu manajer tingkat atas memahami dan memilih tindakan yang baik dalam mencapai tujuan. Job relevant information meningkatkan kinerja melalui pemberian perkiraan yang lebih akurat mengenai lingkungan sehingga dapat dipilih rangkaian tindakan efektif yang terbaik (Adrianto, 2008).

Yusfaningrum (2005) dalam penelitiannya menemukan hasil yang positif dan signifikan pengaruh antara partisipasi penyusunan anggaran terhadap Job Relevant Information. Dalam proses partisipasi, bawahan diberi kesempatan untuk memberikan masukan berupa informasi yang dimilikinya kepada atasan sehingga atasan akan memperoleh pemahaman yang lebih baik tentang pengetahuan yang relevan dengan tugas (task relevant knowledge). Penelitian ini mendapati hasil bahwa terdapat pengaruh positif hubungan antara JRI dengan kinerja manajer meskipun pengaruh tersebut tidak signifikan.

Menurut Marsudi (2007) Job relevant information merupakan variabel intervening, dalam hal ini mengindikasikan bahwa para manajer menggunakan partisipasi sebagai alat yang efisien untuk memperoleh informasi yang berhubungan dengan tugas. Kren (1992), dalam penelitiannya terhadap manajermanajer pada perusahaan manufaktur menemukan bukti bahwa partisipasi anggaran tidak mempengaruhi kinerja manajerial secara langsung. Akan tetapi hubungan partisipasi anggaran dan kinerja manajerial dimediasi oleh Job relevant information. Dari hasil penelitian dari Kren (1992), dan Marsudi (2007), menjelaskan bahwa partisipasi penyusunan anggaran mampu meningkatkan job relevant information dan dengan meningkatnya job relevant information maka kinerja manajerial akan turut meningkat.

Dari beberapa penjelasan diatas, maka dapat diambil hipotesis sebagai berikut: H4: Partisipasi dalam penyusunan anggaran berpengaruh positifdan signifikan terhadap kinerja manajerial dengan di mediasi oleh job relevant information.

\section{METODOLOGI}

\section{Populasi dan Sampel}

Populasi dalam penelitian ini adalah pimpinan cabang, pimpinan capem, pimpinan kedai,dan pimpinan seksi operasional seluruh Bank Riau Kepri. Tujuan 
diadakannya populasi adalah agar kita dapat menentukan besarnya anggota sampel yang diambil dari anggota populasi dan membatasi berlakunya daerah generalisasi.

Sampel adalah bagian dari populasi (sebagian atau wakil populasi yang diteliti), sedangkan penarikan sampel adalah cara pengumpulan data hanya sebagian elemen dari populasi yang diselidiki (Dajan, 1996; 111). Populasi dalam penelitian ini berjulah 214 orang. Dari sebanyak 214 orang populasi tersebut maka dipilih sebanyak 138 orang sampel. Hal ini dikarenakan kriteria dalam pengambilan sampel ini adalah mereka para manajer yang ikut terlibat langsung dalam penyusunan anggaran.

\section{Jenis dan Sumber Data}

Jenis data yang digunakan dalam penelitian ini adalah data subyek (selfreport data). Data subyek diklasifikasikan berdasarkan bentuk tanggapan (respon) yang diberikan salah satunya secara tertulis atau dalam bentuk kuestioner. Kuesioner berisi tanggapan atas pertanyaan tertulis yang diajukan oleh peneliti. Kuesioner dikirimkan kepada kepala cabang, kepala cabang pembantu, kepala kedai dan pimpinan seksi operasional di propinsi Riau dan propinsi Kepulauan Riau.

Sumber data dalam penelitian ada dua yaitu data primer dan data sekunder. Data primer yaitu sumber data penelitian yang diperoleh secara langsung dari sumber asli (tidak melalui media perantara). Data sekunder yaitu sumber data penelitian yang diperoleh peneliti secara tidak langsung melalui media perantara. Dalam penelitian ini. Adapun sumber data primer dalam penelitian ini adalah opini atau pendapat para manajer yang diisi dalam kuesioner, sedangakan data sekundernya adalah data mengenai perusahaan PT. Bank Riau Kepri.

\section{Defenisi Operasional dan Pengukuran Variabel}

\section{Partisipasi penyusunan anggaran}

Partisipasi penyusunan anggaran dalam penelitian ini adalah tingkat seberapa jauh keterlibatandan pengaruh individu di tingkat manager dalam proses penyusunan anggaran yang ada di dalam divisi, cabang atau bagiannya baik secara periodik maupun tahunan. Partisipasi dalam penyusunan anggaran lebih memungkinkan bagi para manajer (sebagai bawahan) untuk melakukan negosiasi dengan atasan mereka mengenai kemungkinan target anggaran yang dapat dicapai. Ada 5 (lima) item pertanyaan yang dipakai untuk mengukur partisipasi dengan menggunakan skala Likert lima poin, dimana skor terendah (poin 1) menunjukkan partisipasi rendah, sedangkan skor tinggi (poin 7) menunjukkan partisipasi tinggi. 


\section{Gaya kepemimpinan}

Gaya kepemimpinan merupakan sikap dan perilaku yang menunjukkan hubungan dekat, saling mempercayai dan saling memperhatikan antara pimpinan dan bawahan. Gaya kepemimpinan diukur dengan menggunakan instrumen yang dikembangkan oleh Gibson (1996) dan pernah digunakan oleh Dianita (2009). Instrumen pengukuran ini terdiri dari 9 (Sembilan) pertanyaan dengan skala 1 sampai 7. Skala 1 Tidak Setuju Sama Sekali yang menunjukkan gaya kepemimpinan yang sangat rendah dan skala 7 Sangat Setuju (SS) yang menunjukkan gaya kepemimpinan sangat tinggi. Jika nilai rata-rata berada diatas skala 4, berarti gaya kepemimpinan berorientasi pada karyawan. Dan jika nilai rata-rata berada dibawah skala 4, berarti gaya kepemimpinan berorientasi pada tugas.

\section{Motivasi}

Motivasi dalam penelitian ini didefinisikan sebagai derajat sampai dimana seorang individu ingin dan berusaha untuk melaksanakan suatu tugas dengan baik (Ghozali, 2002). Masing-masing bagian dari instrumen motivasi untuk pengukurannya menggunakan enam item pertanyaan dengan skala likert tujuh poin. Dimana skor terendah (poin 1) menunjukkan motivasi kerja rendah, sedangkan skor tinggi (poin 7) menunjukkan motivasi kerja tinggi.

\section{Job relevant information}

Informasiyangberhubungandengantugas(JRI),yaituinformasiyang memfasilitasi pembuatan keputusan yang berhubungan dengan tugas. JRI meningkatkan kinerja melalui pemberian perkiraan yang lebih akurat mengenai lingkungan sehingga dapat dipilih rangkaian tindakan efektif yang terbaik. Pengukuran variabelini menggunakan kuesioner yang dikembangkan oleh Kren (1992). Pengukuran variabel ini menggunakan 3 (tiga) buah pertanyaan dengan skala Likert satu sampai dengan lima dimana skor terendah (poin 1) JRI rendah, sedangkan skor tinggi (poin 7) menunjukkan JRI tinggi.

\section{Kinerja Manajerial}

kinerja manajerial yang dimaksud dalam penelitian ini adalah kegiatankegiatanmanajerial yang meliputi : perencanaan, investigasi, pengkoordinasian, evaluasi, pengawasan, pengaturan staff, negosiasi dan perwakilan atau representasi (Mahoney, 1993). Ada 9 (sembilan) item pertanyaan yang dipakai untuk mengukurkinerja manajerial dengan menggunakan skala Likert lima poin, dimana skor terendah (poin 1) menunjukkan kinerja rendah, sedangkan skor tinggi (poin 7) menunjukkan kinerja tinggi.

\section{Metode Analisis Data}

Dalam pengujian hipotesis dalam penelitian ini menggunakanteknik multivariat Structural Equation Modelling (SEM) dan alat analisa yang 
digunakan dalam metode ini adalah software Partial Least Square (PLS). Untuk pengujian hipotesis yang diajukan, dapat dilihat dari besarnya T-statistik.

\section{HASIL PENELITIAN DAN PEMBAHASAN}

\section{Gambaran Umum Responden}

Sampel dalam penelitian ini adalah Pimpinan Cabang, Pimpinan Cabang Pembantu, Pimpinan Kedai, dan Pimpinan Seksi Operasional seluruh PT. Bank Riau Kepri sejumlah 138 orang. Kepada 138 orang sampel ini dikirimkanlah kuesioner ke masing-masing orang dengan cara diantar langsung ataupun kirim melalui surat ke alamat responden yang bersangkutan.

Dari 138 kuesioner yang disebarkan, 103 kuesioner dapat diterima. Terdapat 4 buah kuesioner yang tidak diisi lengkap, dan 14 berisikan data outlier sehingga harus digugurkan. Total data dapat diolah lebih lanjut adalah sebanyak $85(61,59 \%)$.

\section{Analisis Data}

\section{Menilai Outer Model atau Measurement Model}

Terdapat tiga kriteria di dalam penggunaan teknik analisa data dengan Smart PLS untuk menilai outer model yaitu Convergent Validity, Discriminant Validity dan Composite Realiability.

\section{Convergent validity}

Convergent Validity dari model pengukuran dengan refleksif indikator dinilai berdasarkan korelasi antara item score/component score yang diestimasi dengan software PLS. Ukuran refleksif individual dikatakan tinggi jika berkorelasi lebih dari 0,70 dengan konstruk yang diukur. Namun menurut Chin, 1998 dalam Ghozali, 2006 untuk penelitian tahap awal dari pengembangan skala pengukuran nilai Loading o,50 sampai o,60 dianggap cukup memadai. Dalam penelitian ini akan digunakan batas Loading Factor sebesar 0,50. Pada pengujian ini menunjukkan bahwa semua loading factor memiliki nilai di atas 0,50, sehingga konstruk untuk semua variabel tidak ada yang dieliminasi dari model.

\section{Discriminant validity}

Dari pengujian ini dapat dilihat bahwa nilai loading factor untuk setiap indikator dari masing-masing variabel laten telah memiliki nilai loading factor yang lebih besar dibandingkan nilai loading jika dihubungkan dengan variabel laten lainnya. Hal ini berarti bahwa setiap variabel laten telah memiliki discriminant validityyang baik dimana beberapa variabel laten masih memiliki pengukur yang berkorelasi tinggi dengan konstruk lainnya.

Kriteria validity dan reliabilitas juga dapat dilihat dari nilai reliabilitas juga dapat dilihat dari reliabilitas suatu konstruk dan nilai Average Variance 
Extracted (AVE) dari masing-masing konstruk. Konstruk dikatakan memiliki reliabilitas yang tinggi jika akar AVE berada di atas 0,50. Hasil correlationof latent variable dan akar AVE pada penelitian ini dapat disimpulkan bahwa semua konstruk memenuhi kriteria reliabel. Hal ini ditunjukkan dengan nilai akar AVE konstruk lebih tinggi dari pada korelasi antara konstruk dengan variabel latent. Sehingga model dianggap memenuhi kriteria discriminant validity.

\section{Composite Realibility}

Composite Realiability dari blok indikator menunjukkan nilai yang memuaskan atau direkomendasikan diatas 0,70. Composite Realiability dari blok indikator penelitian ini menunjukkan nilai yang memuaskan, yaitu di atas 0,70 sehingga model dianggap memenuhi kriteria Composite Realiability dengan kata lain semua konstruk penelitian reliable untuk diteliti lebih lanjut.

\section{Pengujian Model Struktural (Inner Model)}

Pengujian inner model atau model stuktural dilakukan untuk melihat hubungan antara konstruk, nilai signifikansi dan R-Square dari model penelitian. Model struktural diuji dengan koefisien determinasi (R2). Pada pengujian ini menunjukkan nilai R-square untuk variabel gaya kepemimpinan diperoleh sebesar 0,014457, untuk variabel job relevant informasi diperoleh 0,056563, untuk variabel kinerja manajerial diperoleh sebesar 0,152102, dan untuk motivasi diperoleh 0,020040. Hasil ini menunjukkan bahwa 1,44\% variabelgayakepemimpinandapatdijelaskanolehvariabelpartisipasi penyusunan anggaran, sedangkan 98,56\% dijelaskan oleh faktor lain. 5,65\% variabel job relevant informasi dapat dijelaskan oleh variabel partisipasi penyusunan anggaran, sedangkan 94,35\% dijelaskan oleh faktor lain.15,21\%variabel kinerja manajerial dapat dijelaskan oleh variabel partisipasi penyusunan anggaran, sedangkan 84,79\% dijelaskan oleh faktor lain. 2,004\% variabel motivasi dapat dijelaskan oleh variabel partisipasi penyusunan anggaran, sedangkan 97,996\% dijelaskan oleh faktor lain.

\section{Pengujian Hipotesis dan Pembahasan}

\section{Pengujian Hipotesis Pertama (H1)}

Hasil pengujian hipotesis pertama (H1) menunjukkan bahwa hubungan variabel partisipasi anggaran dengan kinerja manajerial menunjukkan nilai koefisien jalur sebesar 0,2576 dengan nilai t statistik sebesar 2,3304. Nilai tersebut lebih besar dari t-tabel 1,96, ini menunjukkan bahwa hubungan partisipasi penyusunan anggaran dengan kinerja managerial memiliki hubungan langsung. Hal ini berarti bahwa hipotesis pertama terdukung atau dengan kata lain hipotesis 1 diterima 
Tabel 1: Path Coefficients (Mean, STDEV, T-Values)

\begin{tabular}{lrrrrr}
\hline & $\begin{array}{c}\text { Original } \\
\text { Sample (O) }\end{array}$ & $\begin{array}{c}\text { Sample } \\
\text { Mean (M) }\end{array}$ & $\begin{array}{c}\text { Standard } \\
\text { Deviation } \\
\text { (STDEV) }\end{array}$ & $\begin{array}{c}\text { Standard } \\
\text { Error } \\
\text { (STERR) }\end{array}$ & $\begin{array}{c}\text { T Statistics } \\
(\mid \mathbf{O} / \text { STERR|) }\end{array}$ \\
\hline GK -> KM & -0.0433 & -0.114 & 0.0792 & 0.0792 & 0.5463 \\
JR -> KM & 0.2895 & 0.2963 & 0.1149 & 0.1149 & 2.5194 \\
MO -> KM & 0.1618 & 0.2159 & 0.1181 & 0.1181 & 1.3699 \\
PA -> GK & -0.1202 & -0.1453 & 0.0802 & 0.0802 & 1.4987 \\
PA -> JR & -0.2378 & -0.2435 & 0.0774 & 0.0774 & 3.0718 \\
PA -> KM & 0.2576 & 0.2703 & 0.1105 & 0.1105 & 2.3304 \\
PA -> MO & 0.1416 & 0.1769 & 0.108 & 0.108 & 1.3111 \\
\hline
\end{tabular}

Ket : PA: Partisipasi Penyusunan Anggaran, GK : Gaya Kepemimpinan, JR : Job Relevant Informasi, MO : Motivasi, KM: Kinerja Manajerial

Hasil penelitian ini mendukung pernyataan dari Brownel dan McInnes (1986) dan Laberto (2001) yang menemukan bukti bahwa partisipasi penyusunan anggaran mempengaruhi kinerja manajerial. Dengan adanya partisipasi penyusunan anggaran maka kinerja manajerial diharapkan akan lebih meningkat.

\section{Pengujian Hipotesis Kedua (H2)}

Hasil pengujian pada tabel 4.13 menunjukkan bahwa partisipasi penyusunan anggaran tidak berpengaruh langsung terhadap gaya kepemimpinan hal ini ditunjukkan dengan nilai koefisien jalur sebesar -0,120 dengan nilai t sebesar 0,076. Nilai tersebut lebih kecil dari t tabel $(1,96)$. Sedangkan hasil pengujian gaya kepemimpinan terhadap kinerja manajerial menunjukkan nilai koefisien jalur -0,043 dengan nilai t sebesar 0,070. Nilai tersebut kecil dari nilai t-tabel $(1,96)$. Hasil ini menunjukkan bahwa gaya kepemimpinan tidak memiliki pengaruh langsung terhadap kinerja manajerial.

Pengujian mediasi dapat dilakukan apabila terpenuhinya syarat- syatar yang telah ditentukan oleh Baron dan Kenny (1986) yaitu pertama, variabel independen harus signifikan mempengaruhi variabel mediator. Kedua, variabel independen harus signifikan mempengaruhi variabel dependen. Ketiga, variabel mediator harus signifikan mempengaruhi variabel dependen. Kempat, mediasi terjadi jika pengaruh variabel independen terhadap dependen lebih rendah atau menjadi nol. Berdasarkan nilai $t$ sebesar 0,076 pada pengujian pengaruh partisipasi anggaran terhadap gaya kepemimpinan dan 0,070 pada pengujuian pengaruh gaya kepemimpinanterhadap kinerja manajerial, pengujian pengaruh mediasi tidak dapat dilakukan, karena tidak memenuhi persyaratan pertama dan ketiga yang telah ditentukan oleh Baron dan Kenny (1986), dimana variabel independen harus signifikan mempengaruhi variabel mediator dan variabel mediator harus signifikan mempengaruhi variabel dependen. Hal ini berarti bahwa variabel gaya kepemimpinan tidak mampu bertindak sebagai variabel intervening. Dengan demikian hipotesis H2 ditolak. 
Hipotesis kedua (H2) ditolak dikarenakan dalam perusahaan PT. Bank Riau Kepri gaya kepemimpinan tidak mampu mempengaruhi hubungan antara partisipasi penyusunan anggaran dengan kinerja manajerial. Sehingga gaya kepemimpinan seorang manajer tidak memiliki pengaruh dalam proses penganggaran dan dalam penilaian kinerja manajerial. Dalam artian apapun itu gaya kepemimpinan seorang manajer atas tidaklah mempengaruhi kinerja dalam proses partisipasi penyusunan anggaran.

Hasil penelitian sejalan dengan penelitian yang dilakukan oleh Yuniarti (2008) dan Nor (2007). Namun tidak sejalan dengan penelitian Baihaqi (2010) yang menemukan bukti bahwa gaya kepemimpinan mampu bertidak sebagai variabel intervening terhadap hubungan partisipasi penyusunan anggaran dengan kinerja manajerial.

\section{Pengujian Hipotesis Ketiga (H3)}

Hasil pengujian pada tabel 4.13 menunjukkan bahwa partisipasi penyusunan anggaran tidak berpengaruh langsung terhadap motivasi hal ini ditunjukkan dengan nilai koefisien jalur sebesar 0.142 dengan nilai t sebesar 1,357. Nilai tersebut lebih kecil dari t tabel $(1,96)$. Sedangkan hasil pengujian motivasi terhadap kinerja manajerial menunjukkan nilai koefisien jalur 0,162 dengan nilai t sebesar 1,403. Nilai tersebut kecil dari nilai t-tabel $(1,96)$. Hasil ini menunjukkan bahwa motivasi tidak memiliki pengaruh langsung terhadap kinerja manajerial.

Berdasarkan nilai t sebesar 1,357 pada pengujian pengaruh partisipasi anggaran terhadap motivasi dan 1,403 pada pengujuian pengaruh motivasi terhadap kinerja manajerial, pengujian pengaruh mediasi tidak dapat dilakukan, karena tidak memenuhi persyaratan pertama dan ketiga yang telah ditentukan oleh Baron dan Kenny (1986), dimana variabel independen harus signifikan mempengaruhi variabel mediator dan variabel mediator harus signifikan mempengaruhi variabel dependen. Hal ini berarti bahwa variabel motivasi tidak mampu bertindak sebagai variabel intervening. Dengan demikian hipotesis $\mathrm{H}_{3}$ ditolak.

Hipotesis ketiga $\left(\mathrm{H}_{3}\right)$ ditolak dikarenakan dalam perusahaan PT. Bank Riau Kepri motivasi tidak mampu mempengaruhi hubungan antara partisipasi penyusunan anggaran dengan kinerja manajerial. Dengan adanya motivasi tidaklah mempengaruhi kinerja manajerial dalam partisipasinya di penyusunan anggaran perusahaan.

Hasil penelitian tidak sejalan dengan penelitian Laberto (2001) dan Sembiring (2008) yang menemukan bukti bahwa motivasi mampu bertidak sebagai variabel intervening terhadap hubungan partisipasi penyusunan anggaran dengan kinerja manajerial. 


\section{Pengujian Hipotesis Keempat (H4)}

Hasil pengujian pada tabel 4.13 menunjukkan bahwa partisipasi penyusunan anggaran tidak berpengaruh langsung terhadap kinerja manajerial, namun partisipasi penyusunana anggaran berpengaruh langsung terhadap job relevant information (sebagai variabel intervening) dan job relevant information berpengaruh terhadap kinerja manajerial. Maka besarnya pengaruh tidak langsung ini dapat dihitung dengan mengalikan koefisien $(\mathrm{a} \times \mathrm{b})=(0,234 \mathrm{x}$ $0,289)=0,068$

Besarnya Standard error tidak langsungvariabelpartisipasipenyusunan anggaran terhadap kinerja manajerial merupakan perkalian dari pengaruh variabel partisipasi penyusunana anggaran terhadap job relevant information dengan variabel job relevant information terhadap kinerja manajerial.

Nilai t sebesar 2 tersebut lebih besar dari 1,96 yang berarti bahwa parameter mediasi tersebut signifikan. Jadi, model pengaruh tidak langsung dari variabel partisipasi penyusunan anggaran terhadap kinerja manajerial melalui job relevant information terdukung atau dapat diterima. Dengan demikian hipotesis $\mathrm{H}_{4}$ diterima.

Hasil penelitian ini konsisten dengan yang dilakukan oleh Yusfaningrum (2005) dan Marsudi (2007) yang menemukanbukti bahwa variabel job relevant information mampu memediasi hubungan partisipasi penyusunan anggaran dengan kinerja manajerial.

\section{PENUTUP}

\section{Kesimpulan}

Berdasarkan dari hasil penelitian ini dapat disimpulkan sebagai berikut :

1. Hasil pengujian hipotesis pertama menunjukkan bahwa variabel partisipasi penyusunan anggaran berpengaruh positif signifikan terhadap kinerja manajerial. Pengujian ini menerima hipotesis pertama yang menyatakan bahwa partisipasi anggaran berpengaruh terhadap kinerja manajerial.

2. Dari hasil pengujian peneliti menemukan bukti bahwa terdapat hubungan yang tidak langsung antara Partisipasi penyusunan anggaran dengan kinerja manajerial, namun partisipasi penyusunan anggaran memiliki hubungan dengan kinerja manajerial melalui job relevant informasi. Dengan demikian job relevant informasi mampu bertindak sebagai mediasi dalam hubungan partisipasi penyusunan anggaran dengan kinerja manajerial.

3. Dari pengujian dibuktikan gaya kepemimpinan dan motivasi tidak dapat memediasi hubungan antara partisipasi penyusunan anggaran dengan kinerja manajerial. Ini artinya bahwa partisipasi anggaran melalui pengaruhnya terhadap gaya kepemimpinan dan motivasi tidak mampu 
mempengaruhi peningkatan kinerja manajerial.

\section{Keterbatasan}

Penulis sadar akan keterbatasan-keterbatasan yang ada dalam penelitian ini. Keterbatasan ini mungkin mempengaruhitercapainya hasil yang diinginkan. Beberapa keterbatasan penelitian ini adalah :

1. Bahwa pemilihan sampel yang terbatas pada para level manajer Bank Riau Kepri, sehingga penelitian hanya fokus pada satu perbankan daerah.

2. Penelitian ini menggunakan metode quesioner tanpa dilengkapi dengan wawancara atau pertanyaan lisan, sehingga kemungkinan mempengaruhi validitas hasil. Jawaban responden belum tentu mencerminkan keadaan yang sebenarnya dan akan berbeda jika data diperoleh dengan wawancara.

3. Seluruh responden meminta supaya kuesioner ditinggalkan, sehingga peneliti tidak bisa mengendalikan responden yang mengisi kuesioner. Oleh karena itu jawaban responden belum tentu menggambarkan keadaaan sebenarnya.

4. Pengukuran instrumen menggunakan self rating,sihingga cenderung menimbulkan leniency bias (kemurahan hati dalam menilai peran manajerial diri sendiri).

\section{Saran}

Adapun beberapa saran yang dapat dilakukan untuk penelitian mendatang adalah :

1. Penelitian selanjutnya hendaknya memperluas obyek penelitiannya, tidak terbatas pada satu bank daerah saja melainkan lebih dari pada satu bank daerah dan bank umum yang ada di indonesia, agar dapat melakukan perbandingan antara bank yang satu dengan yang lainnya.

2. Penelitian selanjutnya dapat mengembangkan model penelitian dengan menambahkan faktor-faktor lain yang dapat mempengaruhi partisipasi penyusunan kinerja manajerial. Variabel lain yang dapat disarankan untuk dimasukkan kepenelitian selanjutnya adalah komitmen organisasi, budaya organisasi dan kecukupan anggaran.

\section{DAFTAR PUSTAKA}

Adrianto. Yogi. 2008. Analisis Pengaruh Partisipasi Penyusunan Anggaran terhadap Kinerja Manajerial dengan kepuasan kerja,Job Relevant Information dan Kepuasan Kerja sebagai Variabel Moderating. Tesis S2 Program Pasca Sarjana Universitas Diponegoro. Semarang.

Akhyar, Chairil. 2009. Pengaruh Partisipasi Anggaran, Gaya Kepemimpinan Dan Komitmen Organisasi Terhadap Kinerja Manajerial (Studi KasusPada Universitas Malikussaleh Lhokseumawe). Tesis Pasca Sarjana Universitas 
Sumatera Utara. Medan.

Anthony,R.N., Dearden, J and Bedford. 1998. Management Control System. Chicago.II:Irwin: McGraw-hill.

Arfan Ikhsan dan La Ane. 2007. Pengaruh Partisipasi Anggaran Terhadap Senjangan Anggaran Dengan Menggunakan Lima Variabel Pemoderasi. SNA X. 26-28 Juli. pp 1-27.

Ariadi, Dani. 2006. Pengaruh Anggaran Partisipatif Melalui Budaya Organisasi, Gaya Manajemen, Dan Motivasi Kerja Sebagai Variabel Intervening Terhadap Kinerja Manajerial Dan Kepuasan Kerja Pada PT. Socfin Indonesia. Tesis Pasca Sarjana Universitas Sumatera Utara. Medan.

Brownell. P danM.McInnes.1986. Budgetary Participation, Motivation, and Managerial Performance. The Accounting Review. Vol. 61, No.4. pp.587600.

Brownell. P. 1981. Participation in Budgeting Locus of Control and Organizational Effectiveness. The Accounting Review 57. PP. 766-777

Ehrman Suhartono dan Muchammad Solichin. 2006. Pengaruh Kejelasan Sasaran Anggaran Terhadap Senjangan Anggaran Instansi Pemerintah Daerah Dengan Komitmen Organisasi Sebagai Pemoderasi. SNA X. 23-26 Agustus. pp 1-20.

Fahrianta, Riswan Yudhi.2001. Pengaruh Tidak LangsungSistemPenganggaran Terhadap Kinerja Manajerial : Motivasi Sebagai Variabel Intervening. Tesis Program Studi Magister Manajemen Program Pasca Sarjana Universitas Diponegoro, Semarang.

Ferdinand, Augusty, 200o. Structural Equation Modelling dalam Penelitian Manajemen, Badan Penerbit Universitas Diponegoro.

Fuad Mas'Ud. 2005. Survei Diagnosis Organisasional : Konsep dan Aplikasi, Program Magister Manajemen \& Program Magister Sains Akuntansi. UNDIP. Semarang.

Hansen Dan Mowen. 2001. Akuntansi Manajemen. Salemba Empat. Jakarta.

Ghozali. Imam. 2006. Structural Equation Modeling Metode Alternatif Dengan Partial Least Square (PLS). Edisi 3. Undip. Semarang.

Heriyanti, Dewinta. 2007. Analisis Pengaruh Budaya Organisasi, Kepuasan Kerja, Dan Gaya Kepemimpinan Terhadap Kinerja Karyawan Dengan Komitmen Organisasional Sebagai Variabel Interverning (Studi PT. PLN (Persero)Apj Semarang). Tesis Program Studi Magister Manajemen Program Pasca Sarjana Universitas Diponegoro, Semarang.

Idriantoro. Nur dan Supomo. 2002. Metodologi Penelitian Bisnis untuk Akuntansi dan Manajement. Edisi Pertama. BPFE. Yogyakarta. 
Kren Leslie, 1992. Budgetary Participation and Managerial Performance: The Impact of Information and Environmental Volatility. The Accounting Review. July. Pp. 511-526.

Krisler Bornadi Omposunggu dan Icuk Rangga Bawono. 2006. Pengaruh Partisipasi Anggaran Dan Job Relevant Information Terhadap Informasi Asimetris. SNA IX. 23-26 Agustus. pp 1-27.

Laberto, Eddy. 2001. Pengaruh Partisipasi Penyusunan Anggaran Terhadap Kinerja Manajerial Dengan Motivasi Sebagai Variabel Intervening. Tesis Program Studi Magister Manajemen Program Pasca Sarjana Universitas Diponegoro, Semarang.

Mahoney.T.A. T.H. Jerdee, and S.J. Carrol. 1963. Development of Managerial Performance. A ResearchApproach. Cincinati. Ohio: Southwestern Publishing.

Mardiasmo. 2002. Akuntansi Sektor Publik. Andi Offiset. Yogyakarta.

Mariam, Rani. 2009. Pengaruh Gaya Kepemimpinan Dan Budaya Organisasi Terhadap Kinerja Karyawan Melalui Kepuasan Kerja Karyawan Sebagai Variabel Intervening. Tesis Program Studi Magister Manajemen Program Pasca Sarjana Universitas Diponegoro, Semarang.

Marsudi, A. Setya.2001. Pengaruh Gaya Partisipasi Anggaran, Job Relevant Information, Dan Volatilitas Lingkungan Kerja Terhadap Kinerja Manajerial Pada Perusahaan Manufaktur Di Indonesia. Tesis Program Studi Magister Manajemen Program Pasca Sarjana Universitas Diponegoro, Semarang.

Mulyadi (1993), Sistem Perencanaan dan Pengendalian Manajemen. Penerbit Salemba Empat Jakarta.

Natalis,Franky.2002. Analisis Pengaruh Partisipasi Anggaran Terhadap Kinerja Manajerial Dan Kepuasan Kerja Dengan Internal Locus Of Control Dan Peran Manajerial Lini Sebagai Variabel Moderating Pada Pura Group Kudus. Tesis Program Studi Magister Manajemen Program Pasca Sarjana Universitas Diponegoro, Semarang.

Nouri H. and Parker R. J. (1996), The Effect of Organizational Commitment on The Relation Between Budgetary Participation and Budgetary Slack, Behavioral Research in Accounting, vol.8

Nor, Wahyudin. 2007. Desentralisasi Dan Gaya Kepemimpinan Sebagai Variabel Moderating Dalam Hubungan Antara Partisipasi Penyusunan Anggaran Dan Kinerja Manajerial. SNA X. 26-28 Juli. pp 1-27.

Sembiring, Samuel Abel Tanta. 2008. Pengaruh Partisipasi Anggaran Dan Kejelasan Sasaran Anggaran Terhadap Kinerja Manajerial Dengan 
Motivasi Sebagai Variabel Intervening Pada Kawasan Industri Medan. Tesis Program Studi Magister Manajemen Program Pasca Sarjana Universitas Sumatra Utara, Medan.

Sinambela. Elizar. 2003. Pengaruh partisipasi dalam Penyusunan Anggaran terhadap Kinerja Manajerial. Tesis S2 Program Pasca Sarjana Universitas Sumatera Utara. Medan.

Uday. Parrek. 1985. Motivasi Analysis of Organizational Behavior. MAO-B. University Associates, Inc.

Yusfaningrum. Kusnariyanti dan Imam Ghozali. 2005. Analisis Pengaruh Partisipasi Anggaran Terhadap Kinerja Manajerial Melalui Komitmen Tujuan Anggaran dan Job Relevant Information (JRI) sebagai Variabel Intervening (Penelitian Terhadap Perusahaan Manfaktr Di Indonesia). SNA VIII, Solo. 